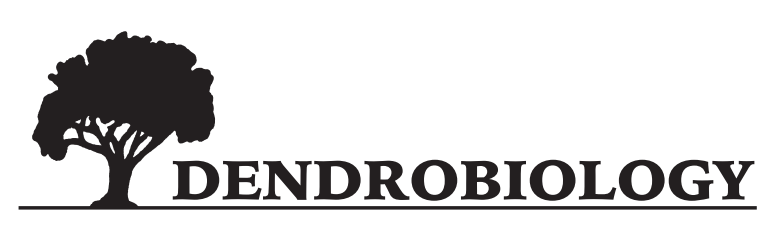

2019, vol. 81, 14-21

http://dx.doi.org/10.12657/denbio.081.002

\author{
Xiaoming Lu, Shalik Ram Sigdel, Binod Dawadi, Yafeng Wang
}

\title{
Climate response of Salix oritrepha growth along a latitudinal gradient on the northeastern Tibetan Plateau
}

Received: 7 November 2018; Accepted: 4 March 2019

\begin{abstract}
Shrubs are widespread at higher altitudes and latitudes. Dendrochronology of shrub growth has been intensively studied in the circumpolar Arctic, Mediterranean and Patagonia. However, relatively little is known about shrub growth responses to climate change on the Tibetan Plateau. Herein, we investigate climate sensitivity of Salix oritrepha growth along a north-south $\left(35-39^{\circ} \mathrm{N}\right)$ latitudinal gradient on the northeastern Tibetan Plateau. Four S. oritrepha shrub sites were selected for dendrochronology study. Pearson and partial correlation analyses were used to estimate strength of the climate sensitivity of the growth time series at each site. We found that not all of the site chronologies show consistent variations. Despite of this, its radial growth was primarily limited by the July mean temperature across the latitudinal gradient, and warming summer climate tends to increase the growth of $S$. oritrepha on the northeastern Tibetan Plateau.
\end{abstract}

Keywords: shrub, radial growth, climate sensitivity, dendrochronology, summer temperature

Addresses: X. Lu, S. R. Sigdel, Key Laboratory of Alpine Ecology, Institute of Tibetan Plateau Research, Chinese Academy of Sciences, Beijing 100101, China, e-mail: luxiaoming@itpcas.ac.cn

B. Dawadi, Central Department of Hydrology and Meteorology, Tribhuvan University, Kathmandu, Nepal

Y. Wang, College of Biology and the Environment, Nanjing Forestry University, Nanjing 210037, China

\section{Introduction}

Shrubland is a key plant community in treeless areas worldwide (Matthews, 1983). As shown by repeat photography, plot survey and dendroecology studies conducted in past decades, recent climate warming has already resulted in acceleration of shrub growth and shrub expansion in the Arctic tundra (Chapin et al., 2005; Forbes et al., 2010; Tape et al., 2012; Elmendorf et al., 2012; Myers-Smith et al., 2015). Such changes are highly relevant to nutrient cycling, surface albedo and biodiversity (Chapin et al., 2005; Wipf \& Rixen, 2010; Bonfils et al., 2012). However, response of shrub growth to warming temperatures is likely to be heterogeneous under different local environment conditions (Ropars et al., 2015; Myers-Smith et al., 2015). Thus, a better understanding on the response of shrub growth to warming temperatures is essential to evaluate spatial heterogeneity of shrub expansion and its influence on tundra and alpine ecosystems.

The climate sensitivity of erect and prostrate shrub growth across the circumpolar Arctic (Myers-Smith et al., 2015), Mediterranean (Gazol \& Camarero, 2012) and alpine sites in Patagonia (Srur \& Villalba, 2009) has been well established. As shown by a recent meta-analysis, the climate sensitivity of shrub growth was not uniform across the tundra biome, with more than half of the study sites exhibiting positive or negative relationships between growth and summer temperatures (Myers-Smith et al., 2015). Species 
interactions were considered to be important factors to mediate growth responses of shrubs to regional climate in the Mediterranean region (Gazol \& Camarero, 2012). Abundant winter precipitation, warmer spring and autumn temperatures tended to enhance the shrub growth in the Patagonia steppe (Srur \& Villalba, 2009). In alpine regions, most studies focused on moist sites (e.g. Bär et al., 2007; Liang \& Eckstein, 2009; Hallinger et al., 2010; Li et al., 2013; Shetti et al., 2018; Weijers et al., 2018), while climate drivers of shrub growth at dry and cold alpine sites are less explored (e.g. Liang et al., 2012; Pellizzari et al., 2017).

The Tibetan Plateau with an average elevation surpassing $4000 \mathrm{~m}$ above the sea level (a.s.l.) provides adequate settings to investigate how alpine shrub growth responds to climate change. Salix oritrepha is an ubiquitous shrub species found throughout alpine area on the northeastern Tibetan Plateau (Fang et al., 2011). Summer temperature is a dominant factor limiting $S$. oritrepha growth above the juniper treeline (Lu et al., 2016). Given its wide distribution range and well-defined annual growth ring, S. oritrepha is an ideal alpine species to quantify climate-growth relationships at the regional scale.

The objective of this study is to investigate climate-growth relationships of $S$. oritrepha along a latitudinal gradient on the northeastern Tibetan Plateau. We expect to detect spatial differences in climate responses of $S$. oritrepha growth. This research will provide important clue to evaluate effects of climate change on alpine ecosystem of the Tibetan Plateau.

\section{Methods}

\section{Study area and climate}

S. oritrepha is a tall deciduous and multi-stemmed shrub species, widespread at high altitudes on the northeastern Tibetan Plateau (Fang et al., 2011). It

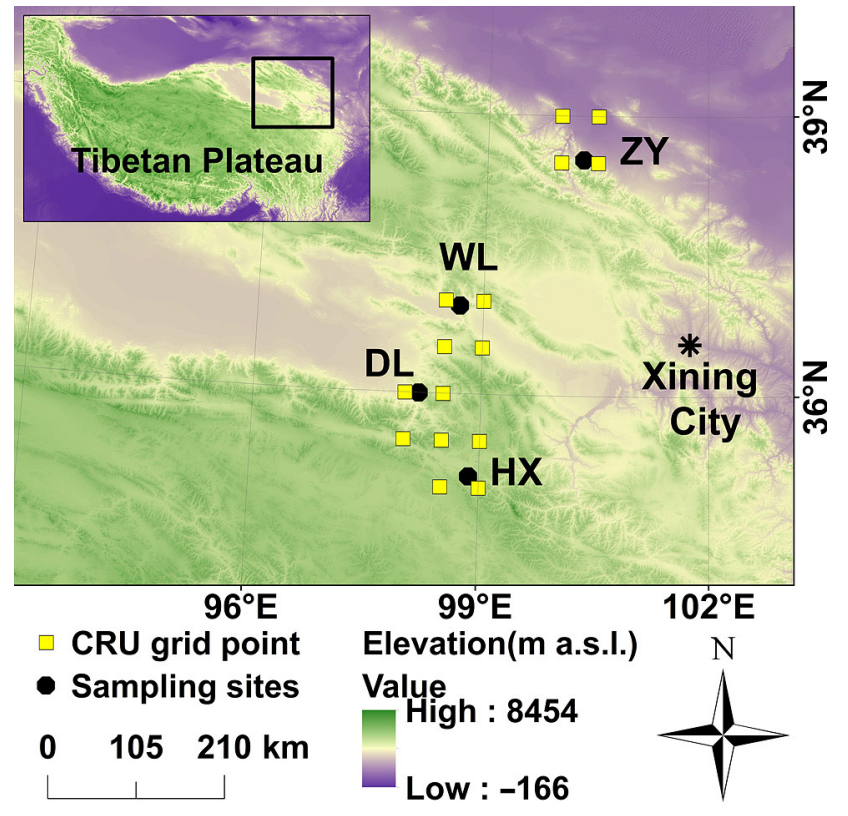

Fig. 1. The study area and four sampling sites (black dots) on the northeastern Tibetan Plateau. The yellow boxes are the climate research unit (CRU) grid points Abbreviations: ZY, Zhangye; WL, Wulan; DL, Dulan; HX, Huashixia.

grows in an erect form, commonly ranging from 0.6$1.2 \mathrm{~m}$ in height. However, we observed that many individuals can reach a height of $1.6 \mathrm{~m}$. It also occupies a wide elevational range (3200-4600 $\mathrm{m}$ a.s.l.) and individuals are distinguishable from one another.

The study was conducted along a latitudinal transect extending from the Qilian Mountains to the Anyemaqen Mountains $\left(35-39^{\circ} \mathrm{N}, 97-100^{\circ}\right.$ E) on the northeastern Tibetan Plateau (Fig. 1). Four $S$. oritrepha sites were selected (from north to south): Zhangye (ZY), Wulan (WL), Dulan (DL) and Huashixia (HX) (see details in Table 1). In the study area, forests are dominated by coniferous tree species of Picea crassifolia from 2300 to $3877 \mathrm{~m}$ a.s.l. and Juniperus przewalskii from 2100 to $4200 \mathrm{~m}$ a.s.1..

Table 1. The locations, features and statistics of S. oritrepha site chronologies

\begin{tabular}{|c|c|c|c|c|}
\hline \multirow{2}{*}{ Variables } & \multicolumn{4}{|c|}{ Site (code) } \\
\hline & Zhangye (ZY) & Wulan (WL) & Dulan (DL) & Huashixia (HX) \\
\hline Latitude $\mathrm{N}\left({ }^{\circ}\right)$ & 38.53 & 36.94 & 36.00 & 35.12 \\
\hline Longitude $\mathrm{E}\left({ }^{\circ}\right)$ & 100.3 & 98.69 & 98.18 & 98.87 \\
\hline Elevation (m a.s.l.) & 3400 & 3828 & 4270 & 4257 \\
\hline Aspect $\left(^{\circ}\right)$ & 19 & 24 & 44 & 52 \\
\hline Dominant tree vegetation & Spruce treeline & Spruce treeline & Juniper treeline & Juniper treeline \\
\hline No. individuals & 27 & 28 & 35 & 27 \\
\hline No. radii & 67 & 76 & 105 & 74 \\
\hline Time span & $1963-2015$ & $1953-2015$ & $1969-2014$ & 1988-2015 \\
\hline Mean ring width $\pm \mathrm{SD}(\mathrm{mm})$ & $0.36 \pm 0.14$ & $0.27 \pm 0.12$ & $0.25 \pm 0.13$ & $0.34 \pm 0.14$ \\
\hline MS & 0.21 & 0.17 & 0.29 & 0.15 \\
\hline $\mathrm{R}_{\mathrm{bar}}$ & 0.26 & 0.3 & 0.32 & 0.34 \\
\hline EPS $>0.85$ since & 1970 & 1975 & 1980 & 1990 \\
\hline
\end{tabular}

Abbreviations: SD, standard deviation; MS, mean sensitivity; $\mathrm{R}_{\text {bar }}$, mean series inter-correlation; EPS, expressed population signal. 


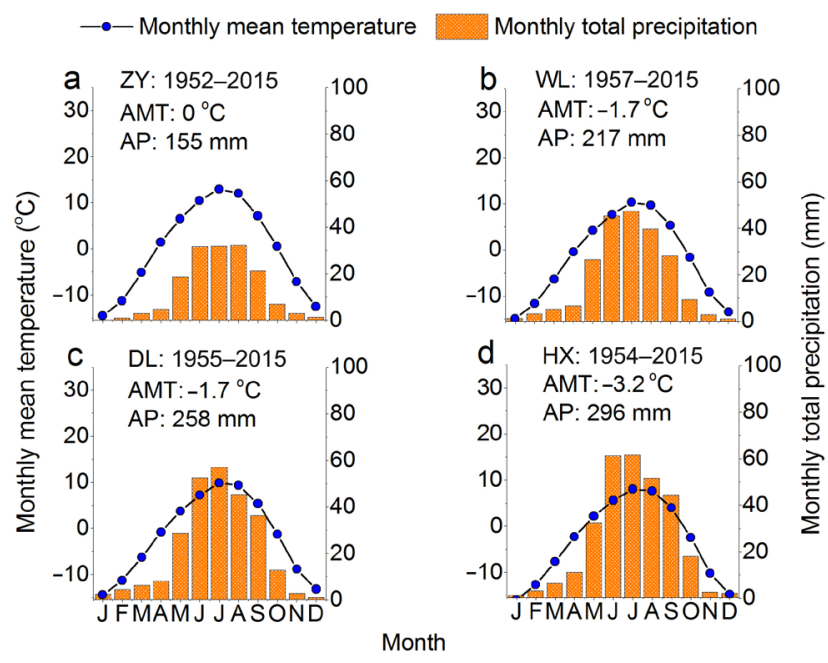

Fig. 2. The monthly climate data (mean temperature and total precipitation) for the grid points of the CRU dataset corresponding to the four study sites (sites' codes are as in Fig. 1). The period with available climate data is shown for each site

Abbreviations: AMT, annual mean temperature; AP, annual total precipitation.

P. crassifolia and $J$. przewalskii form natural treelines from 3385 to $3877 \mathrm{~m}$ a.s.l. and from 3558 to 4250 $\mathrm{m}$ a.s.l., respectively (Zhu et al., 2008; Gou et al., 2012; Liang et al., 2016). P. crassifolia treeline shifted upward 13 to $80 \mathrm{~m}$ during the past 100 years in our study area (Liang et al., 2016).

$S$. oritrepha shrubs were selected from the neartreeline alpine sites (Table 1). ZY (3400 m a.s.l., northeast-facing slope) is situated above the P. crassifolia treeline in the central Qilian Mountains. WL (3828 m a.s.l., northeast-facing slope) and DL (4270 $\mathrm{m}$ a.s.l., northeast-facing slope) sites are above the $P$. crassifolia treeline and the J. przewalskii treeline, respectively. Both of them are located at the eastern margin of the Qaidam Basin. HX (4257 m a.s.l., northeast-facing slope) lies in the alpine steppe on the northwestern Anyemaqen Mountains, where $J$. przewalskii treeline reaches up to $4200 \mathrm{~m}$ a.s.l. (Zhang et al., 2015).

Due to the influence of the Asian monsoon and the Westerly, the study area is characterized by a continental arid climate, with mild summer but dry and cold winter. The gridded dataset of climate research unit (CRU TS4.0, $0.5^{\circ}$ resolution) in study area was used for analyses (Harris et al., 2014; data retrieved from climate explorer webpage, http://climexp. knmi.nl/). The halfway grid points method was used to keep grid point data nearest to the study sites. Annual total precipitation (AP) decreases northward from $296 \mathrm{~mm}$ (HX) to $155 \mathrm{~mm}$ (ZY) (Fig. 2). Annual mean temperature (AMT) increases from $-3.2^{\circ} \mathrm{C}$ (HX) in the south to $0{ }^{\circ} \mathrm{C}(\mathrm{ZY})$ in the north of the study area. Variations in the annual mean temperature from four study sites are highly correlated from
1957 to 2015 ( $r>0.72, P<0.001)$. Correlations of annual total precipitation between four sites are also significant $(r>0.51, P<0.001)$.

\section{Dendrochronological methods}

In April and October 2015, we collected 27 to 35 discs of $S$. oritrepha close to the soil level at ZY, WL, DL and HX (Table 1). We cut these discs from the largest stem of each individual. The discs were air dried, sanded and visually cross dated under stereomicroscope (Stokes \& Smiley, 1996). Ring widths were then measured along two to three radii in Lintab 6 system (Rinntech, Heidelberg, Germany) with a resolution of $0.01 \mathrm{~mm}$. We used COFECHA program to verify the quality of visual cross-dating and measurement (Holmes, 1983).

The ring-width series were detrended using ARSTAN program (Cook \& Krusic, 2008). We first fitted these raw ring-width series by a negative exponential curve, linear regression of any slope or a smoothing spline with $50 \%$ frequency response cutoff width equal to $67 \%$ of the series length. We then obtained standard chronology of each site by averaging (biweight robust means) the detrended ring-width indices. We calculated the mean sensitivity (MS), the mean series inter-correlation $\left(\mathrm{R}_{\text {bar }}\right)$ as well as the expressed population signal (EPS). The MS is a measurement of relative difference between adjacent rings and the $\mathrm{R}_{\mathrm{bar}}$ is the mean correlation between all ring-width series (Fritts, 1976; Briffa \& Jones, 1990). The EPS is usually used as an indicator of the reliability of site chronology with a threshold of 0.85 (Wigley et al., 1984).

\section{Data analysis}

We calculated Pearson correlation coefficients for the four standard chronologies. The period with EPS $\geq 0.85$ was selected for the analysis at each site. Pearson correlation analysis was also used to investigate the climate-growth relationships. We quantified the climate sensitivity of $S$. oritrepha growth as the signal strength of main climate variable. Climate factors include monthly mean temperature and monthly total precipitation for a 15-month period from July of the previous year to September of the current year. Partial correlation analysis was also used to avoid the inter-correlation between climate variables. It measures the linear relationship between two variables after excluding the effect of the third variable.

\section{Results}

Along the latitudinal transect, we developed four standard ring-width chronologies with the longest 


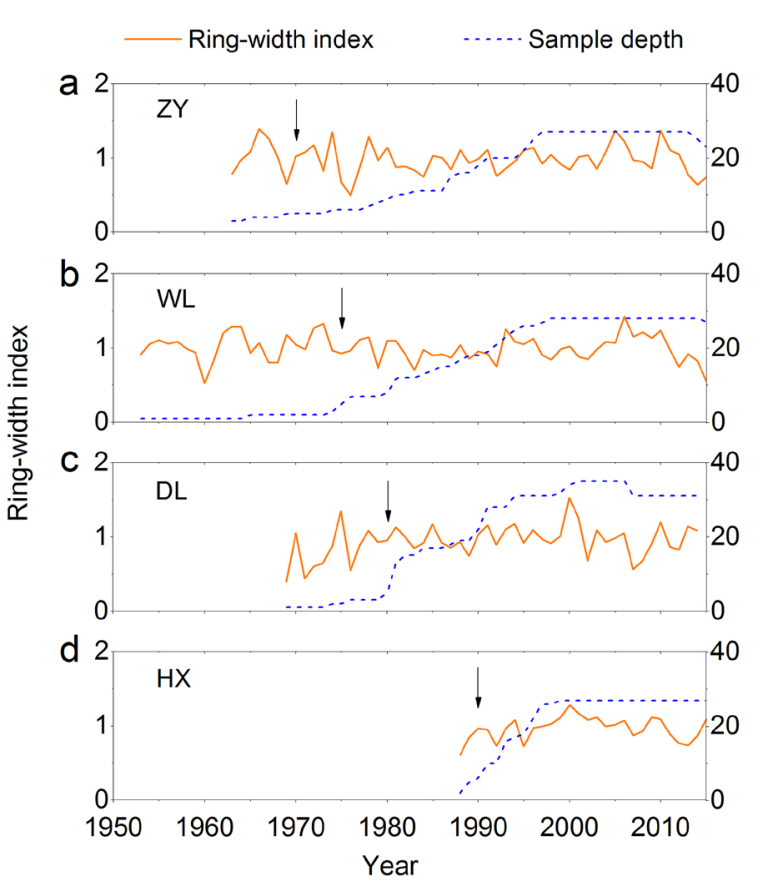

Fig. 3. Standard ring-width chronologies of S. oritrepha shrub in ZY (a), WL (b) and HX (d) sites. The orange lines are ring-width indices (left $\mathrm{x}$ axes) and the dashed blue lines are sample depth (right y axes), respectively. The vertical arrows indicate the years when expression population signal (EPS) value was higher than usually accepted threshold of 0.85 . DL (c) chronology is also shown (Lu et al., 2016)

one (WL) spanning 63 years (Fig. 3; Table 1). Mean ring-width ranged from $0.25 \mathrm{~mm}$ (DL) to $0.36 \mathrm{~mm}$ (ZY). The highest MS was observed at DL (0.29), followed by ZY, WL and HX (Table 1$)$. $\mathrm{R}_{\text {bar }}$ varied from $0.26(\mathrm{ZY})$ to $0.34(\mathrm{HX})$. All of the $S$. oritrepha chronologies showed an EPS value higher than 0.85 when the sample depth reached 5 (including 10-15 ring-width series). Chronologies from $\mathrm{ZY}$ and WL were highly correlated $(r=0.400, P<0.05)$ (Table $2)$. In addition, significant positive correlation was also found between the DL and HX chronologies $(r$ $=0.465, P<0.05)$. However, positive correlations were weak between the chronologies from northern sites (ZY and WL) and southern sites (DL and HX). Negative correlation was also observed between $\mathrm{ZY}$ and DL sites $(r=-0.059, P=0.778)$.

As shown by both Pearson and partial correlation analyses, the radial growth of $S$. oritrepha is

Table 2. Pearson correlations between the four standard chronologies during their common period of 1990-2014. The values above and below the diagonal are significant levels and Pearson correlation coefficients, respectively

\begin{tabular}{crrcc}
\hline & ZY & WL & DL & HX \\
\hline ZY & & 0.047 & 0.778 & 0.450 \\
WL & 0.400 & & 0.843 & 0.158 \\
DL & -0.059 & 0.042 & & 0.019 \\
HX & 0.158 & 0.291 & 0.465 & \\
\hline
\end{tabular}

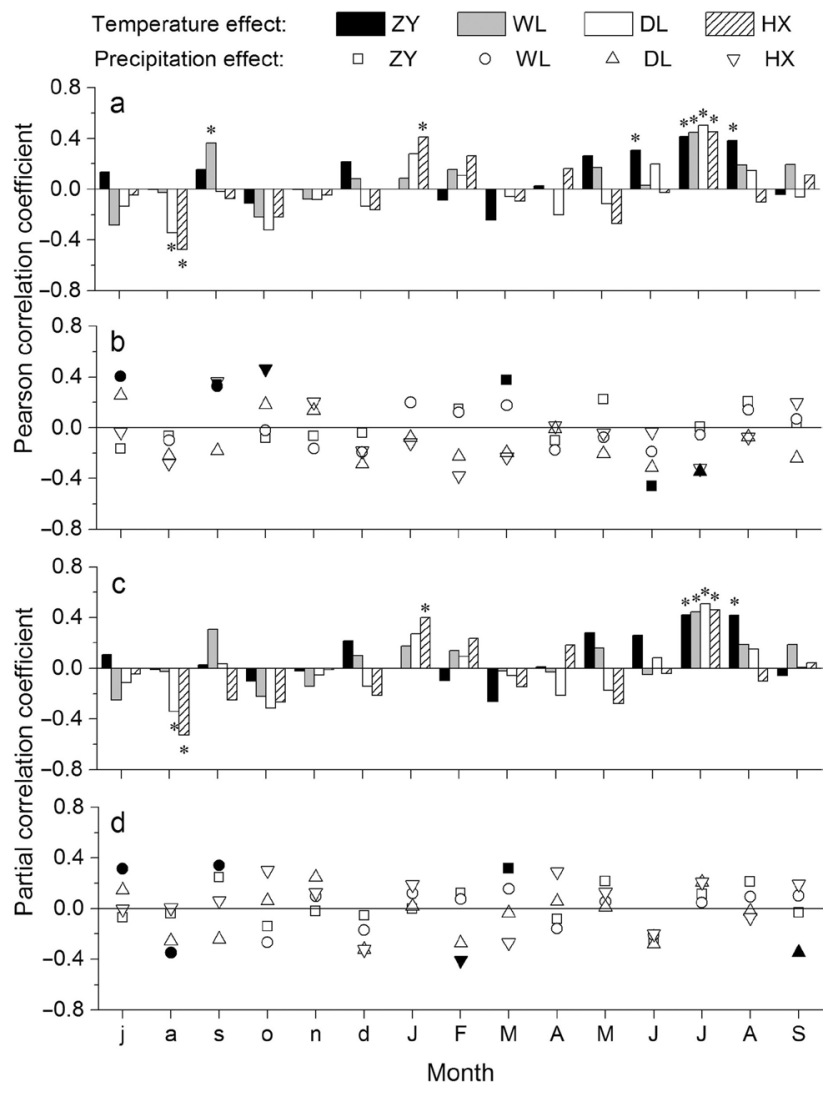

Fig. 4. Pearson (a, b) and partial (c, d) correlation coefficients calculated between four site chronologies (analysis period: 1970-2015 for ZY, 1975-2015 for WL, 1980-2014 for DL and 1990-2015 for HX) and monthly mean temperature and monthly total precipitation records. Monthly climate variables of previous (abbreviated in lowercase) and current year (abbreviated in capital letters) are used for analysis. For the temperature effect, the significant correlation coefficients $(P<0.05)$ are indicated by an asterisk symbol above or below the column bar. For the precipitation effect, the significant correlation coefficients $(P<0.05)$ are indicated by the solid black symbols.

significantly and positively correlated with the July mean temperature across the four sampling sites (Fig. 4a, c). The highest correlation occurs at DL. In addition, the mean temperature in August of the previous year shows significant and negative correlation with the DL and HX chronologies. The ZY chronology has significant and positive correlation with the August mean temperature of the current year. The radial growth of $S$. oritrepha at HX is significantly and positively correlated with the January mean temperature.

The relationships between the four standard chronologies and monthly total precipitation are not uniform (Fig. 4b, d). March precipitation has a significant and positive effect on the growth of S. oritrepha at ZY. The WL chronology is significantly and positively correlated with precipitation in July and September of the previous year. 


\section{Discussion}

The Tibetan Plateau is characterized by a large-area of alpine ecosystem and relatively little is known about the influence of climate change on this biome (Shen et al., 2015; Lu et al., 2019). Taller shrubs are considered to be more sensitive to climate change than low statured shrub species (Myers-Smith et al., 2015). As a dominant tall shrub species across the alpine biome on the northeastern Tibetan Plateau, $S$. oritrepha may serve as an indicator species to show influence of climate change on alpine ecosystem by annual ring records.

In spite of a short age span, S. oritrepha can be used to establish robust ring-width chronology characterized by common signal. During the cross-dating analysis, we found very few wedging and missing rings. The mean ring-widths at DL and WL were similar to those measured in nearby treeline juniper trees (Liang et al., 2006; Zheng et al., 2008). Compared to other arctic willow shrubs, the mean ring-width is wider than prostrate species of $S$. polaris $(0.08 \mathrm{~mm}$, Svalbard) (Buchwal et al., 2013), S. arctica $(0.12 \mathrm{~mm}$, NE Greenland) (Schmidt et al., 2010) and erect species of S. pulchra $(0.21 \mathrm{~mm}$, NE Siberia; $0.19 \mathrm{~mm}$, Alaska) (Blok et al., 2011; Ackerman et al., 2017), but much narrower than erect $S$. alaxensis shrubs (1.0 mm, Victoria Island) (Zalatan \& Gajewski, 2006). The MS is lower than many arctic willow shrubs (Schmidt et al., 2010; Blok et al., 2011). The $\mathrm{R}_{\mathrm{bar}}$ and EPS values confirm that the four standard chronologies are applicable for dendroecological analysis.

The growth variation of $S$. oritrepha was not consistent across the four study sites (Table 2). S. oritrepha growth at the northern sites (ZY and WL) is different from the southern sites (DL and HX). Such result suggested that the growth of $S$. oritrepha was also influence by microsite conditions. This may potentially due to their elevational differences which may lead to differentiation in phenology and growth (Vitasse et al., 2009). Another explanation is that $S$. oritrepha growth is influenced by variation in precipitation. The annual total precipitation gradually decreases northward from HX to ZY (Fig. 2) which could lead to different soil moisture at the site level. Study in the alpine treeline sites in Yukon also showed that willow shrub growth variation is influenced by the soil moisture content in early growth season (Dearborn \& Danby, 2018).

July temperature is a common climate factor driving the growth of $S$. oritrepha across the latitudinal gradient on the northeastern Tibetan Plateau. It is assumed that low temperature drives the onset of the alpine shrub growth (Li et al., 2016). Furthermore, warm summer temperature could benefit new wood tissue formation and more than half of the ring-width is completed in July (Li et al., 2016). In a recent synthesis, summer temperature was found to be the dominant climate variable controlling shrub growth across different taxa and locations in the tundra biome (Myers-Smith et al., 2015). On the southeastern Tibetan Plateau, summer temperature is also a primary limiting factor for the radial growth of alpine rhododendron shrubs (Liang \& Eckstein, 2009; Li et al., 2013; Lu et al., 2015).

Given that our study sites are located at the transition zone between erect trees forming the treeline and $S$. oritrepha shrub, climate-growth relationships between $S$. oritrepha and treeline $P$. crassifolia and $J$. przewalskii trees could be compared. As shown by dendrochronology studies at P. crassifolia and J. przewalskii treelines on the northeastern Tibetan Plateau, the growth of both tree species is also strongly driven by the growth season temperatures (Liu et al., 2005; Liang et al., 2006; Zheng et al., 2008; Zhu et al., 2008; Fang et al., 2009; Liu et al., 2016). Similar growth responses of shrubs and trees to climate have also been reported on the southeastern Tibetan Plateau (Liang \& Eckstein, 2009; Li et al., 2013), Alps (Francon et al., 2017) and Scandes (Bär et al., 2007). In addition, shrub growth shows similar climate signal across gender and species in the northeastern Greenland (Schmidt et al., 2010), Siberian (Blok et al., 2011) and Central Anatolia (Kahveci et al., 2018). However, dwarf shrubs and trees can also respond differently to the climate factors at latitudinal or altitudinal treeline in Mediterranean, Polar and central Alps (Gazol \& Camarero, 2012; Pellizzari et al., 2017). Shrubs are lower stature life forms than trees. Thus, shrub growth is less coupled to air temperatures than nearby trees. Similar growth responses to climate for shrub and coexisting tree indicate suitable hydrothermal conditions for both of them. In our case, $S$. oritrepha shrub and coexisting trees may respond differently to the same climate factor following the rapid climate warming in the future.

The radial growth of $S$. oritrepha did not show common signal of precipitation between four sites. At ZY and WL, annual precipitation is lower than that at DL and HX (Fig. 2). As a result, the growth of S. oritrepha at ZY and WL is likely affected by drought stress. It was supported that precipitation prior to the growing season benefited $S$. oritrepha growth at ZY and WL. The northeastern Tibetan Plateau has experienced climate warming and moistening process in the past three decades (Yang et al., 2014). Based on our results, future climate could enhance the growth of S. oritrepha in our study area.

In summary, S. oritrepha growth is primarily limited by July temperature along the latitudinal gradient on the northeastern Tibetan Plateau, and shows a common climate signal as nearby alpine treeline trees. In our study area, $P$. crassifolia treeline has shifted upward significantly in response to climate warming 
over the past century (Liang et al., 2016). This has already changed the species interactions. We could infer that increased tree cover may limit the growth of $S$. oritrepha shrub and reduce its above-ground productivity in the treeline ecotone. Such a knowledge gap needs to be tested. Future study should assess impacts of climate change and species interaction on $S$. oritrepha population dynamics on the northeastern Tibetan Plateau.

\section{Acknowledgments}

This work is funded by China Postdoctoral Science Foundation (2017M620924) and National Natural Science Foundation of China (41771222). The authors are grateful to the editor and two anonymous referees for providing valuable comments on the manuscript.

\section{References}

Ackerman D, Griffin D, Hobbie SE \& Finlay JC (2017) Arctic shrub growth trajectories differ across soil moisture levels. Global Change Biology 23: 42944302. doi:10.1111/gcb.13677.

Bär A, Bräuning A \& Löffler J (2007) Ring-width chronologies of the alpine dwarf shrub Empetrum hermaphroditum from the Norwegian mountains. International Association of Wood Anatomists Journal 28: 325-338. doi:10.1163/2294193290001644.

Blok D, Sass-Klaassen U, Schaepman-Strub G, Heijmans MMPD, Sauren P \& Berendse F (2011) What are the main climate drivers for shrub growth in Northeastern Siberian tundra? Biogeosciences 8: 1169-1179. doi: 10.5194/bg-8-1169-2011.

Bonfils CJW, Phillips TJ, Lawrence DM, Cameron-Smith P, Riley WJ \& Subin ZM (2012) On the influence of shrub height and expansion on northern high latitude climate. Environmental Research Letters 7: 015503. doi:10.1088/17489326/7/1/015503.

Briffa KR \& Jones PD (1990) Basic chronology statistics and assessment: Methods of dendrochronology applications in the environmental sciences (ed. by Cook ER \& Kairiukstis LA) Kluwer Academic Publishers, pp. 137-152.

Buchwal A, Rachlewicz G, Fonti P, Cherubini P \& Gärtner H (2013) Temperature modulates intra-plant growth of Salix polaris from a high Arctic site (Svalbard). Polar Biology 36: 1305-1318. doi:10.1007/s00300-013-1349-x.

Chapin FS, Sturm M, Serreze MC, McFadden JP, Key JR, Lloyd AH, McGuire AD, Rupp TS, Lynch AH, Schimel JP, Beringer J, Chapman WL, Epstein HE, Euskirchen ES, Hinzman LD, Jia G, Ping CL,
Tape KD, Thompson CDC, Walker DA \& Welker JM (2005) Role of land-surface changes in Arctic summer warming. Science 310: 657-660. doi:10.1126/science.1117368.

Cook E \& Krusic P (2008) A tree-ring standardization program based on detrending and autoregressive time series modeling, with interactive graphics (ARSTAN). Tree-Ring Laboratory, Lamont-Doherty Earth Observatory, Columbia University, Palisades, NY.

Dearborn KD \& Danby RK (2018) Topographic influences on ring widths of trees and shrubs across alpine treelines in southwest Yukon. Arctic Antarctic and Alpine Research 50: e1495445. doi:10. 1080/15230430.2018.1495445.

Elmendorf SC, Henry GHR, Hollister RD, Björk RG, Bjorkman AD, Callaghan TV, Collier LS, Cooper EJ, Cornelissen JHC, Day TA, Fosaa AM, Gould WA, Grétarsdóttir J, Harte J, Hermanutz L, Hik DS, Hofgaard A, Jarrad F, Jónsdóttir IS, Keuper F, Klanderud K, Klein JA, Koh S, Kudo G, Lang SI, Loewen V, May JL, Mercado J, Michelsen A, Molau U, Myers Smith IH, Oberbauer SF, Pieper S, Post E, Rixen Ch, Robinson $\mathrm{CH}$, Schmidt NM, Shaver GR, Stenström A, Tolvanen A, Totland $\varnothing$, Troxler T, Wahren CH, Webber PJ, Welker JM \&Wookey PA (2012) Global assessment of experimental climate warming on tundra vegetation: heterogeneity over space and time. Ecology Letters 15: 164175. doi:10.1111/j.1461-0248.2011.01716.x.

Fang J, Wang Z \& Tang Z (2011) Atlas of woody plants in China: distribution and climate. Springer Berlin Heidelberg.

Fang K, Gou X, Chen F, Peng J, D'Arrigo R, Wright W \& Li M (2009) Response of regional tree-line forests to climate change: evidence from the northeastern Tibetan Plateau. Trees-Structure and Function 23: 1321-1329. doi:10.1007/s00468009-0373-5.

Forbes BC, Fauria MM \& Zetterberg P (2010) Russian Arctic warming and 'greening' are closely tracked by tundra shrub willows. Global Change Biology 16: 1542-1554. doi:10.1111/j.13652486.2009.02047.x.

Francon L, Corona C, Roussel E, Lopez Saez J \& Stoffel M (2017) Warm summers and moderate winter precipitation boost Rhododendron ferrugineum $\mathrm{L}$. growth in the Taillefer massif (French Alps). Science of the Total Environment 586: 1020-1031. doi:10.1016/j.scitotenv.2017.02.083.

Fritts HC (1976) Tree rings and climate. Academic Press, New York.

Gazol A \& Camarero JJ (2012) The performance of Mediterranean subshrubs depends more on microsite than on regional climate conditions. Journal of Vegetation Science 23: 1062-1070. doi:10.1111/j.1654-1103.2012.01429.x. 
Gou X, Zhang F, Deng Y, Ettl GJ, Yang M, Gao L \& Fang K (2012) Patterns and dynamics of treeline response to climate change in the eastern Qilian Mountains, northwestern China. Dendrochronologia 30: 121-126. doi:10.1016/j.dendro.2011.05.002.

Hallinger M, Manthey M \& Wilmking M (2010) Establishing a missing link: warm summers and winter snow cover promote shrub expansion into alpine tundra in Scandinavia. New Phytologist 186: 890899. doi:10.1111/j.1469-8137.2010.03223.x.

Harris I, Jones PD, Osborn TJ \& Lister DH (2014) Updated high-resolution grids of monthly climatic observations - the CRU TS3.10 Dataset. International Journal of Climatology 34: 623-642. doi:10.1002/joc.3711.

Holmes RL (1983) Computer assisted quality control in tree-ring dating and measurement. TreeRing Bulletin 1983: 69-78.

Kahveci G, Alan M \& Köse N (2018) Distribution of juniper stands and the impact of environmental parameters on growth in the drought-stressed forest-steppe zone of Central Anatolia. Dendrobiology 80: 61-69. doi:10.12657/denbio.080.006.

Li X, Rossi S, Liang E \& Camarero JJ (2016) Temperature thresholds for the onset of xylogenesis in alpine shrubs on the Tibetan Plateau. Trees-Structure and Function 30: 2091-2099. doi:10.1007/ s00468-016-1436-z.

Li Z, Liu G, Fu B, Zhang Q, Ma K \& Pederson N (2013) The growth-ring variations of alpine shrub Rhododendron przewalskii reflect regional climate signals in the alpine environment of Miyaluo Town in Western Sichuan Province, China. Acta Ecologica Sinica 33: 23-31. doi:10.1016/j.chnaes.2012.12.004.

Liang E, Lu X, Ren P, Li X, Zhu L \& Eckstein D (2012) Annual increments of juniper dwarf shrubs above the tree line on the central Tibetan Plateau: a useful climatic proxy. Annals of Botany 109: 721-728. doi:10.1093/aob/mcr315.

Liang E \& Eckstein D (2009) Dendrochronological potential of the alpine shrub Rhododendron nivale on the south-eastern Tibetan Plateau. Annals of Botany 104: 665-670. doi:10.1093/aob/mcp158.

Liang E, Shao X, Eckstein D, Huang L \& Liu X (2006) Topography -and species-dependent growth responses of Sabina przewalskii and Picea crassifolia to climate on the northeast Tibetan Plateau. Forest Ecology and Management 236: 268-277. doi:10.1016/j.foreco.2006.09.016.

Liang E, Wang Y, Piao S, Lu X, Camarero JJ, Zhu H, Zhu L, Ellison AM, Ciais P \& Peñuelas J (2016) Species interactions slow warming-induced upward shifts of treelines on the Tibetan Plateau. Proceedings of the National Academy of Sciences of the United States of America 113: 4380-4385. doi:10.1073/pnas.1520582113.
Liu X, Qin D, Shao X, Chen T \& Ren J (2005) Temperature variations recovered from tree-rings in the middle Qilian Mountain over the last millennium. Science in China Series D-Earth Sciences 48: 521-529. doi:10.1360/03yd0063.

Liu Y, Sun C, Li Q \& Cai Q (2016) A Picea crassifolia tree-ring width-based temperature reconstruction for the Mt. Dongda region, Northwest China, and its relationship to large-scale climate forcing. Plos One 11: e0160963. doi:10.1371/journal. pone.0160963.

Lu X, Camarero JJ, Wang Y, Liang E \& Eckstein D (2015) Up to 400-year-old Rhododendron shrubs on the southeastern Tibetan Plateau: prospects for shrub-based dendrochronology. Boreas 44: 760-768. doi:10.1111/bor.12122.

Lu X, Huang R, Wang Y, Sigdel SR, Dawadi B, Liang E \& Camarero JJ (2016) Summer temperature drives radial growth of alpine shrub willows on the northeastern Tibetan Plateau. Arctic Antarctic and Alpine Research 48: 461-468. doi:10.1657/ Aaar0015-069.

Lu X, Liang E, Wang Y, Babst F, Leavitt SW \& Camarero JJ (2019) Past the climate optimum: Recruitment is declining at the world's highest juniper shrublines on the Tibetan Plateau. Ecology 100: e02557. doi:10.1002/ecy.2557.

Matthews E (1983) Global vegetation and land-use: new high-resolution data-bases for climate studies. Journal of Climate and Applied Meteorology 22: 474-487.

Myers-Smith IH, Elmendorf SC, Beck PSA, Wilmking M, Hallinger M, Blok D, Tape KD, Rayback SA, Macias-Fauria M, Forbes BC, Speed JDM, Boulanger-Lapointe N, Rixen C, Lévesque E, Schmidt NM, Baittinger C, Trant AJ, Hermanutz L, Collier LS, Dawes MA, Lantz TC, Weijers S, Jørgensen RH, Buchwal A, Buras A, Naito AT, Ravolainen V, Schaepman-Strub G,Wheeler JA, Wipf S, Guay KC, Hik DS \& Vellend M (2015) Climate sensitivity of shrub growth across the tundra biome. Nature Climate Change 5: 887-891. doi:10.1038/ nclimate2697.

Pellizzari E, Camarero JJ, Gazol A, Granda E, Shetti $\mathrm{R}$, Wilmking M, Moiseev P, Pividori M \& Carrer M (2017) Diverging shrub and tree growth from the Polar to the Mediterranean biomes across the European continent. Global Change Biology 23: 3169-3180. doi:10.1111/gcb.13577.

Ropars P, Lévesque E \& Boudreau S (2015) How do climate and topography influence the greening of the forest-tundra ecotone in northern Québec? A dendrochronological analysis of Betula glandulosa. Journal of Ecology 103: 679-690. doi:10.1111/1365-2745.12394.

Schmidt NM, Baittinger C, Kollmann J \& Forchhammer MC (2010) Consistent dendrochronological 
response of the dioecious Salix arctica to variation in local snow precipitation across gender and vegetation types. Arctic Antarctic and Alpine Research 42: 471-475. doi:10.1657/1938-424642.4.471.

Shen M, Piao S, Dorji T, Liu Q, Cong N, Chen X, An S, Wang S, Wang T \& Zhang G (2015) Plant phenological responses to climate change on the Tibetan Plateau: research status and challenges. National Science Review 2: 454-467. doi:10.1093/ nsr/nwv058.

Shetti R, Buras A, Smiljanic M \& Wilmking M (2018) Climate sensitivity is affected by growth differentiation along the length of Juniperus communis L. shrub stems in the Ural Mountains. Dendrochronologia 49: 29-35. doi:10.1016/j.dendro.2018.02.006.

Srur AM \& Villalba R (2009) Annual growth rings of the shrub Anarthrophyllum rigidum across Patagonia: Interannual variations and relationships with climate. Journal of Arid Environments 73: 1074-1083. doi:10.1016/j.jaridenv.2009.06.008.

Stokes MA \& Smiley TL (1996) An introduction to tree-ring dating. University of Arizona Press, Tucson.

Tape KD, Hallinger M, Welker JM \& Ruess RW (2012) Landscape heterogeneity of shrub expansion in Arctic Alaska. Ecosystems 15: 711-724. doi:10.1007/s10021-012-9540-4.

Vitasse Y, Delzon S, Bresson CC, Michalet R \& Kremer A (2009) Altitudinal differentiation in growth and phenology among populations of temperate-zone tree species growing in a common garden. Canadian Journal of Forest Research 39: 1259-1269. doi:10.1139/X09-054.

Weijers S, Beckers N \& Löffler J (2018) Recent spring warming limits near-treeline deciduous and ever- green alpine dwarf shrub growth. Ecosphere 9: e02328. doi:10.1002/ecs2.2328.

Wigley TML, Briffa KR \& Jones PD (1984) On the average value of correlated time series, with applications in dendroclimatology and hydrometeorology. Journal of Climate and Applied Meteorology 23: 201-213.

Wipf S \& Rixen C (2010) A review of snow manipulation experiments in Arctic and alpine tundra ecosystems. Polar Research 29: 95-109. doi:10.1111/ j.1751-8369.2010.00153.x.

Yang K, Wu H, Qin J, Lin C, Tang W \& Chen Y (2014) Recent climate changes over the Tibetan Plateau and their impacts on energy and water cycle: A review. Global and Planetary Change 112: 79-91. doi:10.1016/j.gloplacha.2013.12.001.

Zalatan R \& Gajewski K (2006) Dendrochronological potential of Salix alaxensis from the Kuujjua River area, western Canadian Arctic. Tree-Ring Research 62: 75-82. doi:10.3959/1536-109862.2.75.

Zhang H, Shao X \& Zhang Y (2015) Which climatic factors limit radial growth of Qilian juniper at the upper treeline on the northeastern Tibetan Plateau? Journal of Geographical Sciences 25: 11731182. doi:10.1007/s11442-015-1226-3.

Zheng Y, Liang E, Zhu H \& Shao X (2008) Response of radial growth of Qilian juniper to climatic change under different habitats. Journal of Beijing Forestry University 30: 7-12.

Zhu H, Zheng Y, Shao X, Liu X, Xu Y \& Liang E (2008) Millennial temperature reconstruction based on tree-ring widths of Qilian juniper from Wulan, Qinghai Province, China. Chinese Science Bulletin 53: 3914-3920. doi:10.1007/s11434008-0400-8. 